Protestantismo em Revista é licenciada sob uma Licença Creative Commons.

http://dx.doi.org/10.22351/nepp.v45i1.3817

\title{
O LUGAR DAS RELIGIÕES NO DEBATE PÚBLICO DA CONTEMPORANEIDADE: LAICIDADE, DIVERSIDADE E FUNDAMENTALISMO(S)
}

\author{
The Place of Religions in the Contemporary Public Debate: \\ Laicism, Diversity and Fundamentalism(s)
}

\author{
Celso Gabatz* \\ Ezequiel Hanke*
}

\begin{abstract}
Resumo:
A sociedade brasileira caracteriza-se pela diversidade religiosa. A relação entre Estado e Religião é marcada pelos processos advindos da laicização do Estado moderno com possíveis desdobramentos na quebra de paradigmas, de conceitos, de valores, através de adaptações e readaptações. A Constituição Federal de 1988 na esteira das demais constituições republicanas estabeleceu a laicidade estatal, definindo e normatizando as relações com as instituições religiosas. Não é de se estranhar o surgimento de crises, colisões de interesses e demandas particulares quando a liberdade religiosa não é reconhecida como expressão da dignidade humana e quando a laicidade não é a base para a argumentação de uma colaboração construtiva na consolidação de um Estado Democrático de Direito alicerçado na vivência da cidadania, do respeito e da alteridade, dos direitos humanos, da diversidade e do bem comum. A proposta do artigo é compreender a incidência histórica da religião na esfera pública e tematizar algumas questões acerca da laicidade nos seus desdobramentos com a liberdade religiosa, os fundamentalismos e a diversidade na perspectiva da equidade e da justiça social.
\end{abstract}

Palavras-Chave: Laicidade; Religião; Diversidade; Fundamentalismos.

\begin{abstract}
:
Brazilian society characterized by religious diversity. The relation between State and religion its marked by the processes that arise from the laicization of the modern state with possible consequences in breaking paradigms, concepts, values, through adaptations and re-adaptations. The Federal Constitution of 1988 on the mat of the other republican constitutions established state laicism, defining and standardizing relations with religious institutions. It is not surprising crises, collisions of interests and particular demands when religious freedom is not recognized an expression of human
\end{abstract}

[Texto recebido em outubro de 2019 e aceito em novembro de 2019, com base na avaliação cega por pares realizada por pareceristas ad hoc]

* Pós-Doutorando. Faculdades EST. E-mail: gabatz12@hotmail.com

** Doutorando. Faculdades EST. E-mail: ezehanke@yahoo.com.br 
dignity and when laicism it's not basis for the argument of constructive collaboration in the consolidation of a democratic rule of law founded on the experience of citizenship, respect and otherness, human rights, diversity and the common good. The purpose of this article is to comprehend the historical incidence of religion in the public sphere and theme some matters regarding laicism in its consequences for religious freedom, fundamentalism and diversity from the perspective of equity and social justice.

Keywords: Laicism; Religion; Diversity; Fundamentalism.

\section{Introdução}

A laicidade não é uma criação contemporânea, mas parte da modernidade, tendo como embasamento a tradição cristã protestante e as doutrinas clássicas do Estado esboçadas pelo jus naturalismo de John Locke $^{1}$ e pelos ideais contratualistas descortinados por Thomas Hobbes. ${ }^{2}$ Na perspectiva de um Estado liberal, ambos sugerem a separação entre as esferas pública e privada, com a consequente busca por uma neutralidade estatal em nome da laicidade. Este tem sido um dos dilemas do constitucionalismo contemporâneo que vive às voltas com o desafio de compreender o fenômeno religioso a partir do significado que as relações entre a religião e o Estado suscitam no sentido de condicionar formas de organização sociais concernentes aos direitos fundamentais.

Hoje, há um inevitável crescimento da força pública da religião. Isso tem feito com que a influência de algumas tradições religiosas na esfera pública seja controvertida e, por vezes, ambivalente em uma sociedade cada vez mais marcada pelo pluralismo e pela complexidade. Diante da impossibilidade de respostas definitivas ou adequadas a muitas questões pertinentes, o debate religioso tanto no âmbito do Judiciário, do Legislativo e até mesmo do Executivo, vem desafiando para uma reorganização de demandas com o intuito de garantir a equidade, a tolerância, alteridade e a perspectiva de que não sejam exacerbados os conflitos socioculturais.

1 Em sua Carta sobre a Tolerância, escrita durante o exílio na Holanda, Locke lançou vários pressupostos condizentes à separação entre a Igreja e o Estado, à neutralidade estatal e à própria liberdade e tolerância religiosa numa época marcada por conflitos entre protestantes e católicos e de lutas políticas entre a Coroa e o Parlamento na Inglaterra. Estes conflitos levaram à Revolução Gloriosa de 1688 que pôs fim ao absolutismo monárquico, consagrando a supremacia do parlamento e afirmando os direitos individuais. "Considero que acima de todas as coisas é necessário distinguir exatamente as funções do governo civil daquelas da religião, e estabelecer a demarcação precisa entre um e outro. Se isso não for feito, não será possível pôr um fim às controvérsias que sempre surgirão entre aqueles que têm, ou pelo menos pretendem ter, uma preocupação com a salvação das almas de um lado, e, de outro, pela segurança da comunidade civil" (LOCKE, 1964, p. 243).

2 Na obra Leviatã o autor busca conceber o Estado a partir de um hipotético estado de natureza, apolítico, marcado pela competição, pelo orgulho, pelos conflitos, pelas guerras, inclusive com motivações religiosas. No entanto, existiria um caminho para a paz, por meio da instituição do Estado civil e do contrato social no qual o Leviatã (homem poderoso e governante supremo) seria capaz de preservar a ordem e pôr fim aos conflitos. O absolutismo de Hobbes enfatiza a necessidade da indivisibilidade dos poderes soberanos e lança as bases do pensamento liberal positivista propondo uma separação ontológica entre o Estado e a sociedade, bem como um respeito absoluto à lei. Para Hobbes "os dissídios religiosos constituíam uma permanente ameaça de morte, decorrente da luta de todos contra todos. Daí que o Estado deveria garantir a existência de um espaço público pacificado, no qual a religião teria lugar, desde que a título privado e na condição de que os princípios morais e o seu proselitismo não perturbassem as regras do direito ditado pelo Soberano" (CATROGA, 2006, p. 228).

Protestantismo em Revista | São Leopoldo | v. 45, n. 02 | p. 07-26| jan./jun. 2019

Disponível em: <http://periodicos.est.edu.br/index.php/nepp> 
A laicidade pode ser diretamente relacionada a dois direitos fundamentais do constitucionalismo contemporâneo: igualdade e liberdade de crença. ${ }^{3}$ Em uma sociedade pluralista como a brasileira, com tantas crenças e opções religiosas, o princípio da igualdade converte-se em um instrumento indispensável ao tratamento de todos os seus indivíduos com respeito e equidade. Já em relação à liberdade religiosa individual, ainda que haja garantia constitucional, a laicidade caracteriza-se como uma diretriz capaz de interditar a promiscuidade entre os poderes públicos e algumas doutrinas religiosas. ${ }^{4}$

É importante destacar que o Brasil estabeleceu uma concepção hierárquica e desigual a respeito da construção de um espaço público laico que permitiu a constituição de uma arena pública, na qual as regras de acesso aos bens disponibilizados pelo Estado não são gerenciadas de forma universalista e igualitária para todos os credos. Tal situação gerou uma espécie de dissonância entre as regras impessoais e universais impostas pela esfera pública e os princípios hierárquicos, desiguais e personalistas presentes na esfera e no espaço público brasileiro.

A inexistência de um princípio universalista e de tratamento igual e uniforme que pudesse abranger todos os sistemas religiosos inviabilizou o pleno reconhecimento dos direitos de certas matrizes religiosas, promovendo o acesso particularizado e desigual de determinadas religiões ao espaço público brasileiro, como se um sistema religioso fosse mais legítimo que o outro. ${ }^{5}$ Desta maneira, mesmo com o movimento de laicização do Estado brasileiro, "em nenhum momento ou lugar, as religiões deixaram de ser uma 'questão de Estado'". 6

O caráter laico do Estado, que lhe permite separar-se e distinguir-se das religiões, oferece à esfera pública e à ordem social a possibilidade de convivência da diversidade e da pluralidade humana. Permite, também, a cada um dos seus, individualmente, a perspectiva da escolha de ser ou não crente, de associar-se ou não a uma determinada instituição religiosa. ${ }^{7} \mathrm{E}$, decidindo por crer, ou tendo o apelo para tal, é a laicidade do Estado que garante, a cada um, a própria possibilidade da liberdade de escolher em que e como crer, ou simplesmente não crer, enquanto é plenamente cidadão, em busca e no esforço de construção da igualdade.

Tão básico é o direito à liberdade de crença ${ }^{8}$ presente no foro íntimo de cada pessoa, que qualquer ameaça, incluindo a que se volta para a própria possibilidade de sua

CANOTILHO, José Joaquim Gomes. Direito Constitucional. Coimbra: Livraria Almedina, 1993.

4 MARTINS FILHO, Ives Gandra da Silva; NOBRE, Milton Augusto de Brito (Coord.). O Estado laico e a liberdade religiosa. São Paulo: LTr, 2011.

5 DAMATTA, Roberto. O que faz o Brasil, Brasil? Rio de Janeiro: Rocco, 1986.

6 MONTERO, P. \& ALMEIDA, R. "O campo religioso brasileiro no limiar do século: problemas e perspectivas" In: RATTNER, H. (Org.). Brasil no limiar do século XXI. São Paulo: Edusp, 2000, p.326.

7 MAFRA, Maria Clara. Na Posse da Palavra: religião, conversão e liberdade pessoal em dois contextos nacionais. Lisboa: Imprensa de Ciências Sociais, 2002.

8 O processo de afirmação da liberdade religiosa vem desde tempo longínquo e, especialmente no Medievo, teve sua aparição destacada na Carta do Convênio entre o Rei Afonso I de Aragon e os Mouros de Tudela em 1119, em que se assegurava a liberdade de trânsito dos Mouros e o respeito aos seus costumes religiosos. 
existência, torna-se ameaça à integridade da identidade de cada um, de grupos e da própria sociedade. A realidade representada por uma multiplicidade de significados acabará suscitando novas possibilidades de organização das relações sociais, multiplicando e diferenciando novos campos de dominação simbólica e explicitando caminhos nos quais os sujeitos irão consolidar sua(s) identidade(s). ${ }^{9}$

\section{Os percursos da laicidade e da liberdade religiosa no Brasil}

Rui Barbosa considerou a liberdade religiosa como a mais importante das liberdades sociais. "De todas as liberdades sociais, nenhuma é tão congenial ao homem, e tão nobre, e tão frutificativa, e tão civilizadora, e tão pacífica, e tão filha do Evangelho, como a liberdade religiosa" ${ }^{10}$ A liberdade religiosa enquanto direito fundamental supõe a complexidade de vertentes subjetivas e objetivas, individuais e coletivas, de dimensões negativas e positivas, vinculando-se aos entes públicos e privados com manifestações de crença e culto, de ordem institucional e procedimental. Por se tratar de um direito fundamental, deveria ser interpretado sob o prisma da liberdade e não sob o enfoque teológico de uma "verdade". ${ }^{11}$

O Brasil se tornou um Estado laico com a Proclamação da República em 188912. Desta maneira, aconteceu oficialmente a separação entre Estado e Igreja e iniciou a lenta secularização de algumas demandas estatais - por exemplo, dos registros de nascimento, casamento e a administração dos cemitérios - antes sob os cuidados da Igreja Católica. Isto não significou, entretanto, a retirada de certos privilégios da Igreja Católica. O lobby católico na Constituinte de 1891 conseguiu impedir a aprovação da lei da mão-morta, pela qual se pretendia despojar os bens materiais da Igreja. Igualmente, as ordens e congregações religiosas continuaram atuando. As subvenções ainda permaneceram e em certas localidades a obtenção de documentos continuou a ser possível apenas pelas mãos dos

Aparição que se fizera como antecipação da tolerância que somente ganharia corpo mais de quatrocentos anos depois. Mais comum, todavia, foram os conflitos entre o poder secular e religioso, que projetava para o campo jurídico frequentes esforços de definição do campo de influência de cada um dos mandos (SAMPAIO, 2004, p. 142).

9 GIUMBELLI, Emerson. Religião, estado e modernidade: notas a propósito de fatos provisórios. Revista de Estudos Avançados. São Paulo, v.18, n. 52, 2004, p.1-13.

10 BARBOSA, Rui. Obras Completas, Vol. 4. Tomo 1, O Papa e o Concílio. Rio de Janeiro: Fundação Casa de Rui Barbosa, 1877, p. 419.

11 WEINGARTNER, Jaime Neto. Liberdade Religiosa na Constituição: fundamentalismo, pluralismo, crenças, cultos. Porto Alegre: Livraria do Advogado, 2007, p. 61.

12 Enquanto colônia do Império português, de 1500 até 1822, o catolicismo era religião oficial do Estado. Com a ascensão do Império no Brasil, embora o catolicismo tivesse status de credo oficial, foi permitido o surgimento de outras denominações religiosas. Com a queda do Império em 1889, foi promulgada a nova Constituição em 1891. Nela, a liberdade religiosa figurou como elemento importante. De acordo com o Art. 72: $\S 3^{\circ}$ "Todos os indivíduos [sic] e confissões religiosas podem exercer publica [sic] e livremente o seu culto, associando-se para esse fim adquirindo bens, observadas as disposições do direito commum [sic]" (RIBEIRO, 1991). 
religiosos. ${ }^{13}$ Mesmo com a separação constitucional em relação ao Estado "a Igreja ainda ocupava espaços consideráveis nas áreas da saúde, educação, lazer e cultura". ${ }^{14}$

Ainda que tenha consagrado a liberdade religiosa e a separação entre a Igreja e o Estado, o código penal republicano tipificava como crimes as práticas do espiritismo, a magia, a cartomancia e o curandeirismo.

Não havia [...] em relação à liberdade de culto, possibilidade de garantir espaço oficial para crenças e religiões que fossem, simultaneamente, doutrinárias e práticas, ou seja, tivessem um pé na modernidade teórico-científica e na busca de princípios e pressupostos lógicos (causas e efeitos comprováveis) e outro pé no empirismo de tradições legitimadas por reiteradas atribuições de significados a acontecimentos cartesianamente desconectados. ${ }^{15}$

De acordo com o pensamento recorrente neste período, as tradições de matriz africana, indígena, espírita, faziam parte de um universo marcado pela irracionalidade, pelo subdesenvolvimento, pelo atraso. Tratava-se, portanto, de uma compreensão bastante diversa da vislumbrada no âmbito da fé cristã, de forma especial, na tradição católica e nas igrejas ligadas ao protestantismo histórico, tidas como coadunadas com a modernidade, com o mundo racional, o progresso e os padrões europeus. ${ }^{16}$

O estudo da história constitucional brasileira e a compreensão da identidade nacional são essenciais para entender o significado e os limites da liberdade religiosa e da laicidade. A religião faz parte da vida do povo brasileiro e é um elemento que a despeito das garantias acerca da laicidade e da liberdade religiosa nas constituições republicanas, ainda assim, realça traços muito significativos e preocupantes desta nas formas de atuação do Estado, bem como no seu simbolismo, articulação e implantação de políticas públicas de promoção da igualdade, inclusão e cidadania.

O grande desafio para a conjuntura brasileira sempre foi de referendar a garantia de uma laicidade aberta, acolhedora, incondicional e que proporcionasse a realização de um pluralismo em um estado democrático de direito. Isso significa pensar e vivenciar uma hospitalidade que pudesse permitir o acolhimento e a recepção do outro. De sua religião, seus símbolos, suas liturgias e práticas de forma que a liberdade religiosa não fosse restringida, mas garantida e promotora da unidade na pluralidade.

Em termos conceituais, de acordo com Daniel Sarmento a laicidade adotada na maioria das democracias contemporâneas opera em duas direções:

Por um lado ela salvaguarda as diversas confissões religiosas do risco de intervenções abusivas do Estado nas suas questões internas, concernentes a aspectos

13 MAINWARING, Scott. Igreja católica e política no Brasil (1916-1985). São Paulo: Brasiliense, 1989.

14 MARIANO, Ricardo. Análise sociológica do crescimento pentecostal no Brasil. Tese (Doutorado em Sociologia) - Universidade de São Paulo, São Paulo, 2001, p. 146.

15 SCHRITZMEYER, Ana Lúcia Pastore. Sortilégio de Saberes: curandeiros e juízes nos tribunais brasileiros (1900-1990). São Paulo: IBCCRIM, 2004, p.138.

16 MONTERO, Paula. Secularização e espaço público: a reinvenção do pluralismo religioso no Brasil. Etnográfica: São Paulo. Maio de 2009, 13 (1) p. 7-16. 
como os valores e doutrinas professados, a forma de cultuá-los, a sua organização institucional, os seus processos de tomada de decisões, a forma e o critério de seleção de seus sacerdotes e membros [...]. Mas, de outro lado, a laicidade também protege o Estado de influências indevidas provenientes da seara religiosa, impedindo todo tipo de confusão entre o poder secular e democrático, em que estão investidas as autoridades públicas, e qualquer confissão religiosa, inclusive majoritária. ${ }^{17}$

É importante salientar que a doutrina constitucionalista brasileira mesmo com determinadas prerrogativas legais, ainda assim, não oferece uma orientação segura a respeito da liberdade religiosa. Em geral, a análise reveste-se de um caráter formalista, limitado pela apresentação genérica de uma ideia sem ressaltar a importância do direito em destaque. ${ }^{18}$ Neste sentido, discutir a liberdade religiosa no Brasil passa por alguns assuntos como a questão da presença dos símbolos religiosos nos espaços públicos, a presença do ensino religioso nas escolas púbicas, feriados religiosos e respeito aos dias de guarda, assistência religiosa confessional no âmbito de instituições públicas, imunidade tributária, cooperação entre igrejas e Estado e, de forma especial, a influência política de alguns grupos religiosos nas instâncias deliberativas de poder. ${ }^{19}$

Se dada religião é tomada como a "melhor" ou a mais "correta", comparativamente às outras que estejam presentes na sociedade, e sejam quais forem os argumentos usados, automaticamente o grupo de adeptos dessa religião passará a gozar de privilégios e distinção que criarão meandros de exclusão às demais. ${ }^{20}$ Se prevalecer o argumento da maioria estatística que tantas vezes é utilizado como base para a reivindicação de privilégios, mais em risco se coloca a democracia, pois esta estaria subjugada a determinados dados que não poderiam justificar que o indivíduo viesse a ser desprezado em sua condição humana, sendo ele igual aos demais e partícipe da pluralidade, na qual se realiza a dignidade humana. ${ }^{21}$

De acordo com Jónatas Machado a liberdade religiosa situa-se no discurso jurídicoconstitucional tendo como premissa e valor de igual dignidade e liberdade de todos os cidadãos, procurando apresentar um conceito de religião e de liberdade religiosa dotado de um grau de inclusão compatível com aqueles valores que afastem dos domínios das opções de fé e da vivência religiosa qualquer forma de coerção e discriminação jurídica ou social.

O exercício da liberdade religiosa individual e coletiva supõe a proteção do exercício da liberdade de associação religiosa em sentido amplo, incluindo a constituição de pessoas coletivas de natureza e finalidade religiosa dotadas dos necessários direitos de auto definição doutrinal e autodeterminação moral e autogoverno institucional

17 SARMENTO, Daniel. O Crucifixo nos Tribunais e a Laicidade do Estado. In: Roberto Lorea. (Org.). Em defesa das Liberdades Laicas. Porto Alegre: Livraria do Advogado, 2008. p. 190-191.

18 LEITE, Fábio Carvalho. Estado e Religião. A Liberdade Religiosa no Brasil. Curitiba: Juruá, 2014.

19 RODRIGUES, Eder Bomfim. Estado Laico e Símbolos Religiosos no Brasil: As Relações entre Estado e Religião no Constitucionalismo Contemporâneo. Curitiba, Juruá, 2014.

20 LOREA, Roberto (org.). Em defesa das liberdades laicas. Porto Alegre: Livraria do Advogado, 2008.

21 SARMENTO, Daniel. Livres e iguais: Estudos de direito constitucional. Rio de Janeiro: Lumen Juris, 2006. 
[...]. O Estado tem que ser garantidor de igual dignidade e liberdade de todos os cidadãos e grupos de cidadãos, religiosos ou não.22

A pesquisadora francesa Danièle Hervieu-Léger ${ }^{23}$ se vale da teoria weberiana para explicar o papel da religião. Para a pesquisadora francesa, as crenças teriam afinidades eletivas em relação ao ethos econômico e social. O que acontece na contemporaneidade seria uma aceitação de afinidades eletivas entre a individualidade religiosa e a individualidade da vida moderna. Hervieu-Léger parte do reconhecimento da dificuldade em delimitar com clareza o conceito de religião tendo em vista o dado de uma fragilização das separações entre sagrado e profano nas sociedades modernas.

Na mesma direção delineada por Hervieu-Léger, um dos precursores da ideia da construção social da realidade, Thomas Luckmann, ${ }^{24}$ refere que a religião se torna invisível na contemporaneidade e se dissemina de forma difusa, fazendo com que suas manifestações extrapolem os limites restritos dos espaços convencionais, deslocando-se para outras áreas da vida humana em sociedade como a política e a mídia. Neste sentido, múltiplas são as possibilidades de expressão sem seguir os contornos demarcados pelas instituições. Forjase um horizonte de vastas possibilidades onde, de acordo com Paulo Barreira Rivera:

[...] não há mais campo religioso estável, e os compromissos de longa duração deixaram de ser norma. Diversos tipos de opções religiosas e múltiplos produtos religiosos são oferecidos dia a dia nos templos e nos meios de comunicação. Religião exclusiva é coisa do passado. O sagrado apresenta-se multiforme, pouco hegemônico e, sobretudo, em constante movimento. ${ }^{25}$

A grande diferença que há entre um Estado que se baseia na ordem religiosa e o laico é que neste último os seres humanos são desafiados a plenificar as relações humanas a partir de ações de forma respeitosa e com o objetivo de consolidar as prerrogativas da alteridade, do entendimento e da igualdade cidadã. ${ }^{26}$ Já na fusão da esfera privada com a esfera pública que faz o estado religioso, haverá o apelo ao sobrenatural ou àquele "absoluto transcendente", crível, se assim se desejar, mas limitado a uma parcela da população.

A influência estratégica da religião no contexto brasileiro, sobretudo cristã e católica, mas, nos últimos tempos, evangélica e neopentecostal, ${ }^{27}$ ilustra uma realidade na qual não é possível delimitar com clareza a laicidade mesmo que esta seja amparada pelo

22 MACHADO, Jónatas E. M. Estado Constitucional e Neutralidade Religiosa. Porto Alegre, Livraria do Advogado, 2013, p.146.

23 HERVIEU-LÉGER, Daniele. O peregrino e o convertido - a religião em movimento. Petrópolis: Vozes, 2008.

24 LUCKMANN, Thomas. A Religião Invisível. São Paulo: Olho d'água/Loyola, 2014.

25 RIVERA, Dario Paulo Barrera. Fragmentação do sagrado e crise das tradições na pós-modernidade. In: TRASFERETTI, José (Org.). Teologia na Pós-modernidade. São Paulo, Paulinas, 2003. p. 438.

26 ARENDT, Hannah. Origens do totalitarismo. São Paulo: Companhia das Letras, 1998.

27 No último Censo realizado no ano de 2010, por exemplo, é possível verificar que os evangélicos chegaram a $22 \%$ da população, sendo que, em 2000 eram 15,4\%; católicos representam 64,6\%, enquanto em 2000 eram $73,6 \%$; pessoas que se declararam sem religião somam $8 \%$ da população (INSTITUTO BRASILEIRO DE GEOGRAFIA E ESTATÍSTICA - IBGE. Censo demográfico 2010. Características gerais da população, religião e pessoas com deficiência. Rio de Janeiro: 2010). 
seu princípio constitucional. Há que ser observado que uma separação entre Estado e religião nos moldes de um modelo liberal é algo bastante utópico, desafiador e subjetivo.

A crença religiosa, por definição, sempre será de âmbito pessoal, podendo abranger uma coletividade, mas não atribuir tal premissa ao Estado. O reconhecimento de que a maioria do povo brasileiro é religioso, cristão e católico, é uma constatação sociológica e não jurídica. ${ }^{28}$ Uma análise mais apurada da história constitucional brasileira consegue esmiuçar o fato de que os problemas relacionados à liberdade religiosa e às relações entre Estado e Religião pouco decorrem das normas, mas de sua interpretação quase sempre em um sentido particular e contingenciada por ambiguidades infraconstitucionais.

A partir da realidade brasileira acima descrita, é importante destacar algumas questões pertinentes para ampliar e aprofundar a discussão em pauta. Caberia, entrementes, perguntar a partir de quais referências poderia ser possível compreender com maior clareza as profundas mudanças ocorridas no campo religioso brasileiro? ${ }^{29}$ De igual forma, qual o sentido das repercussões nos usos e as apropriações do espaço público por uma religiosidade historicamente consolidada? ${ }^{30} \mathrm{E}$, por fim, qual o papel ocupado pela religião em meio às transformações da sociedade moderna? ${ }^{31}$

\section{Fundamentalismo(s) religioso(s) e respeito à diversidade}

Ao longo da história do Brasil, na qual a colonização se fez presente, a escravidão e o autoritarismo contribuíram para o sentimento de inferioridade de muitos grupos de pessoas. A ideologia da degeneração dos mestiços, o ideal de branqueamento e o mito da democracia racial foram os mecanismos de dominação ideológica poderosa e que permanecem no imaginário social e dificultam a equidade. ${ }^{32}$

O historiador protestante Martin Dreher avalia ser importante lembrar que a modernidade se caracteriza pelo surgimento de esperanças e promessas de redenção para uma humanidade cada vez mais carente de sentido.

A emancipação de Deus levou a uma maior exploração do humano. A emancipação da mulher levou a que ela pudesse ser mais facilmente explorada no mercado de trabalho e no consumismo sexista [...]. Num mundo em que a autoridade

28 ÁVILA, Humberto. Teoria dos Princípios: da definição à aplicação dos princípios jurídicos. São Paulo: Malheiros, 2004.

29 FISCHMANN, Roseli. Estado Laico. São Paulo: Memorial da América Latina, 2008.

30 ORTIZ, Renato. Anotações sobre religião e globalização. Revista Brasileira de Ciências Sociais, v. 16, n. 47, Out. 2001, p. 59-74.

31 MARTELLI, Stefano. A religião na sociedade pós-moderna: entre secularização e dessecularização. São Paulo: Paulinas, 1995.

32 Gilberto Freyre foi um dos pioneiros do "mito da democracia racial" apregoando que existiria, no Brasil, a igualdade de oportunidades para brancos, negros e mestiços. A disseminação desse mito permitiu esconder desigualdades raciais, que ainda podem ser constatadas nas práticas discriminatórias de acesso ao emprego, nas dificuldades de mobilidade social da população negra e que recebe remuneração inferior à do branco pelo mesmo trabalho e tendo a mesma qualificação profissional. A falta de conflitos étnicos não caracteriza ausência de discriminação, mas este silêncio favorece o "status quo" que, por sua vez, beneficia a classe dominante. (FREYRE, 2001). 
desmorona, o fundamentalista se sabe abrigado por uma autoridade que escapa à dúvida, à problematização e à dissolução modernas [...]. O fundamentalista experimenta a sociedade que o cerca em decadência moral e anômica, sem lei e sem normas [...]. Com isso o fundamentalismo se torna convidativo e atraente para uma parcela significativa da humanidade, pois oferece segurança em meio a verdades que se desvanecem, porto seguro em meio a pluralidades, a relativizações e dissoluções das certezas antigas. ${ }^{33}$

O fenômeno religioso faz parte da cultura humana, e, portanto, cada religião é peculiar, por expressar diferentes linguagens, diferentes formas de acreditar, de celebrar, de se relacionar com a diversidade e de simbolizar vivências. A partir deste pano de fundo é que na sociedade brasileira, estão presentes inúmeras formas de expressão religiosa, advindas desta diversidade cultural que nos constitui como uma nação sui generis. O grande desafio continua sendo o conhecimento e o respeito ao outro de acordo com a sua especificidade.

A diversidade religiosa brasileira não produz conflitos bélicos de grande impacto, mas são inúmeras as situações que confluem para ampliar a violência e a intolerância na medida em que "[...] o preconceito existe e se manifesta pela humilhação imposta àquele que é diferente, outras vezes o preconceito se manifesta pela violência simbólica" ${ }^{34}$ É neste contexto que pode ser verificado que as atitudes de rejeição e exclusão de alguns grupos em relação a outros geralmente ocorre porque os indivíduos não conseguem ver as culturas diferentes das suas, e, para tanto, julgam a partir do seu ponto de vista, desconhecendo o outro “[...] a priori, pré-estabelecido antes de análise, estudo e reflexão. O medo do diferente, discriminações socialmente propagadas e opiniões distorcidas podem formar em nossa mente julgamentos apressados e rigidez de pensamento" ${ }^{35}$

Talvez pensar o multiculturalismo fosse um dos caminhos para combater os preconceitos e discriminações ligados à etnia, religião, gênero, deficiência, idade e cultura, constituindo assim uma nova perspectiva para uma sociedade como a brasileira que é composta por diversas etnias, nas quais as características da identidade, como cor da pele, modo de falar, diversidade religiosa, são definidoras de mobilidade e posição social na nossa sociedade. Cabe, pois, observar as especificidades das diferenças e vê-las no plano da coletividade.

A consolidação de parâmetros para uma vivência alinhada com os desafios da contemporaneidade implica na criação de mecanismos que motivem a pensar na perspectiva da diversidade e que, sobretudo, ouse questionar o cotidiano, saiba compreender e respeitar o jeito de ser do outro, assumindo nuances históricas de que a nossa sociedade é multicultural. Se a realidade se encontra centrada na dominação cultural de um grupo ou de uma corrente ideológica de caráter fundamentalista, será preciso perceber o

33 DREHER, Martin N. Para Entender o Fundamentalismo. São Leopoldo: Editora UNISINOS, 2002, p. 88-90.

34 URI - Iniciativa das Religiões Unidas de Curitiba. Diversidade religiosa e direitos humanos. Curitiba: Gráfica da Assembleia Legislativa do Estado do Paraná, 2007, p. 4.

35 INCONTRI, Dora; BIGHETO, Alessandro César. Ensino Religioso sem Proselitismo. É Possível? São Paulo: Mandruvá, 2005, p. 4. 
multiculturalismo ${ }^{36}$ como o caminho para reconhecer a alteridade e o direito à diferença dos grupos que se sentem excluídos do processo social. ${ }^{37}$

O plano nacional de direitos humanos estabeleceu em suas diretrizes algumas prerrogativas para assegurar a garantia da igualdade na diversidade. Sublinhou o respeito às crenças e a liberdade de culto, bem como a garantia jurídica para assegurar uma laicidade por parte do Estado através de algumas ações programáticas:

a) Instituir mecanismos que assegurem o livre exercício das diversas práticas religiosas, assegurando a proteção do seu espaço físico e coibindo manifestações de intolerância religiosa.

b) Promover campanhas de divulgação sobre a diversidade religiosa para disseminar cultura da paz e de respeito às diferentes crenças.

d) Estabelecer o ensino da diversidade e história das religiões, inclusive as derivadas de matriz africana, na rede pública de ensino, com ênfase no reconhecimento das diferenças culturais, promoção da tolerância e na afirmação da laicidade do Estado.

e) Realizar relatório sobre pesquisas populacionais relativas a práticas religiosas, que contenha, entre outras, informações sobre número de religiões praticadas, proporção de pessoas distribuídas entre as religiões, proporção de pessoas que já trocaram de religião, número de pessoas religiosas não praticantes e número de pessoas sem religião. 38

É importante destacar que a tolerância necessita ser fomentada pelo conhecimento, pela abertura dialogal, pela liberdade de pensamento, de consciência e de crença. Representa a harmonia nas diferenças. Não se consolida apenas enquanto um dever suscitado pelas premissas éticas, mas representa uma necessidade política e jurídica. As diferenças religiosas não podem e nem deveriam ser justificativas para apoiar qualquer ação de violência ou perseguição, pois os indivíduos possuem antropologicamente e legalmente uma constituição humana pautada na ideia ilimitada de liberdade, recebida tanto pelos que

36 Em termos conceituais o pesquisador jamaicano, já falecido, Stuart Hall, pontua de forma crítica a perspectiva multicultural e o multiculturalismo. "Multicultural é um termo qualificativo. Descreve as características sociais e os problemas de governabilidade apresentados por qualquer sociedade na qual diferentes comunidades culturais convivem e tentam construir uma vida em comum, ao mesmo tempo em que retêm algo de sua identidade 'original'. [...] multiculturalismo é um termo substantivo. Refere-se às estratégias e políticas adotadas para governar ou administrar problemas de diversidade e multiplicidade gerados pelas sociedades multiculturais" (HALL, 2002. p. 50).

37 De acordo com a pesquisadora, militante feminista e pós-doutora em teologia, Rosângela Angelin, a "construção da identidade respeitando as diferenças é um processo bastante complexo, principalmente se considerando que a tendência da maioria dos grupos sociais é a de 'colonizar' o outro, buscando criar uma 'monocultura'. Para isto, o contexto social e o poder imbuído nas relações sociais do capitalismo vigente tem se encarregado, de forma bastante incisiva, de hierarquizar as identidades combatendo as diferenças e buscando 'unificar' mundialmente sua cultura de dominação e subordinação [...]". Por fim, acrescenta que "[...] a busca pela dignidade da pessoa humana na sociedade multicultural pode ser viabilizada através dos Direitos Humanos e Fundamentais, perpassando também pelo caminho da democracia, garantindo que cidadãos e cidadãs possam decidir sobre políticas públicas, criação de leis e outras decisões do Estado" (ANGELIN, 2010. p. 21; 31-32).

38 Programa Nacional de Direitos Humanos (PNDH-3) / Secretaria Especial dos Direitos Humanos da Presidência da República - Brasília: SEDH/PR, 2010, p. 122-123. 
não creem, quanto por aqueles que creem em um Ser Superior, conforme uma determinada concepção teológica diversa da maioria.

A possibilidade da convivência entre as diferentes religiões através do respeito mútuo em meio às diferenças, incluindo os cidadãos que não professam qualquer confissão religiosa, faz-se através de caminhos que permitam indicar meios para respaldar a paz e a democracia a partir de uma cultura dos direitos humanos. Ainda que seja necessário ampliar esta perspectiva no Brasil, este aspecto parece ser possível tão somente pelo diálogo e pelo estabelecimento de ações conjuntas que proporcionam a garantia de liberdade e o respeito pela diversidade religiosa. ${ }^{39} \mathrm{Em}$ recente entrevista no programa televisivo espaço público o conhecido teólogo, conferencista e escritor Leonardo Boff afirmou:

Hoje quase todas as religiões estão doentes, doentes de fundamentalismo e aí, o atraso. Porque as pessoas ficam rígidas, não dialogam, excluem. A função principal da religião é dar aquela aura que o ser humano precisa para dar um sentido mais profundo à vida. ${ }^{40}$

Segundo levantamento do Disque 100, da Secretaria de Direitos Humanos da Presidência da República, as denúncias de intolerância religiosa cresceram mais de 600\% de 2011 a 2012. ${ }^{41}$ A ONG Safernet Brasil recebeu de 2006 a 2012, quase 300.000 denúncias anônimas de páginas e perfis em redes sociais com teor de intolerância religiosa, direcionadas, principalmente contra as religiões de matriz africana. ${ }^{42}$

Os desafios, demandas e possibilidades entabuladas no âmbito do pluralismo religioso na realidade brasileira contemporânea, reforçam a articulação de grupos "conservadores" que embasam as suas ações sublinhadas pelo entendimento de que a modernidade fez emergir a decadência moral, social, cultural e política. Esta decadência estaria diretamente ligada a um "liberalismo teológico" dos movimentos de esquerda, a suposta subversão promovida pelo feminismo, o crescimento da "libertinagem sexual", a ameaça das fações políticas de esquerda, o afrouxamento do papel das autoridades, das leis, punição aos infratores e o aumento da criminalidade.

\section{A relevância das questões religiosas no debate público}

Em diversos países os debates se tornaram relevantes por delinear caminhos para resguardar a garantia dos direitos fundamentais e das liberdades individuais e uma convivência mais harmoniosa diante da diversidade. Na França, por exemplo, mesmo com

39 ORTIZ, Renato. Anotações sobre religião e globalização. Revista Brasileira de Ciências Sociais, v. 16, n. 47, Out. 2001, p. 59-74.

40 BOFF, Leonardo. In: http://jornalobservatorio.com.br/2015/04/28/leonardo-boff-participa-doprograma-espaco-publico/. Acesso em 03 de Jun. 2019.

41 INTOLERÂNCIA RELIGIOSA. In:

http:/ / www12.senado.gov.br/jornal/edicoes/2013/04/16/intolerancia-religiosa-e-crime-de-odio-e-ferea-dignidade. Acesso em 01 de jun. 2019.

42 SAFERNET. In: http://www.safernet.org.br/site/noticias/intoler\%C3\%A2ncia-religiosa-\%C3\%A9crime-\%C3\%B3dio-fere-dignidade. Acesso em 02 de Jun.2019. 
a Revolução Francesa, o grande acontecimento para a formação de um novo conceito jurídico para a laicidade do Estado, o debate em torno da liberdade religiosa continua sendo buscado pela sociedade civil, nos meios acadêmicos, nos diferentes órgãos estatais com o mérito de ampliar estas demandas como constitutivas de uma cidadania plena. ${ }^{43}$

$\mathrm{Na}$ Itália, as discussões acerca da laicidade foram muito importantes para a consolidação política e jurídica em torno do processo de unificação da nação. O Estado italiano foi constituído de forma laica, o que segundo a doutrina liberal, significou a neutralidade, imparcialidade, separação da Igreja e distância de qualquer religião. Esta realidade acabou por fundamentar a força política eclesiástica enquanto protagonista no âmbito do direito internacional com a criação do Estado do Vaticano através do Tratado de Latrão em 1929. Não é por caso que o catolicismo continua tendo uma forte inserção política e cultural em solo italiano, mas sem impedir o devido respeito às diferentes tradições religiosas existentes. ${ }^{44}$

Em Portugal sempre existiram fortes ligações do Estado com a Igreja Católica Romana. Esta grande proximidade é imprescindível para a compreensão das relações existentes entre Estado e religião em nosso país desde o período colonial, principalmente diante da criação de um sistema harmônico e interdependente entre o âmbito político e religioso. A existência, por exemplo, do Tribunal da Santa Inquisição, foi importante para a manutenção do monopólio nas colônias até o período das reformas promovidas pelo Marquês de Pombal. ${ }^{45}$

A proclamação da República em Portugal, posterior a do Brasil, em 1911, permitiu a liberdade religiosa de forma ampla, inclusive nas formas arquitetônicas. A laicidade portuguesa consagrou a separação entre o público e o privado, estabeleceu obrigações às instituições e aos responsáveis pelos cultos. Houve proibição de vestes talares fora dos templos e o impedimento na publicação de bulas sem a prévia autorização das autoridades competentes do Estado. Foram asseguradas a liberdade e igualdade religiosa nas escolas públicas e privadas. Em 2004, no entanto, foram atualizadas questões elencadas na Concordata entre a Santa Sé (Vaticano) e o Estado Português preconizado no acordo de 1940. Nele, há uma incidência de privilégios ao catolicismo que continua sendo uma força política e institucional muito determinante. ${ }^{46}$

Atualmente na América Latina ${ }^{47}$ é possível apontar para diversos casos em que o Estado reconhece apenas uma religião como oficial, ou então, cria privilégios com um status jurídico diferenciado. Este é o caso da Argentina, Bolívia e Costa Rica. Embora haja liberdade de culto, a Argentina prescreve a manutenção do culto católico, como consta na

43 RODRIGUES, Eder Bomfim. Estado Laico e Símbolos Religiosos no Brasil: As Relações entre Estado e Religião no Constitucionalismo Contemporâneo. Curitiba, Juruá, 2014, p.147-175.

44 RODRIGUES, 2014, p. 176-196.

45 ADRAGÃO, Paulo. A Liberdade Religiosa e o Estado. Coimbra: Almedina, 2002.

46 RODRIGUES, 2014, p. 196-243.

47 ORO, Ari Pedro; URETA, Marcela. Religião e política na América Latina: uma análise da legislação dos países. Revista Horizontes Antropológicos, Porto Alegre, ano 13, n. 27, jan./jun. 2007, p. 281-310. 
sua Constituição: "El Gobierno federal sostiene el culto católico, apostólico, romano" ${ }^{48}$ A Bolívia recentemente aprovou a sua nova Constituição que destitui a religião Católica como oficial e afirma que "El Estado respeta y garantiza la libertad de religión y creencias espirituales de acuerdo a sus cosmovisiones y la independencia del Estado con la religión" ${ }^{49}$

Já na Constituição Federal de Costa Rica de 1949, consta “La Religión Católica, Apostólica, Romana, es la del Estado, el cual contribuye a su mantenimiento, sin impedir el libre ejercicio en la República de otros cultos que no se opongan a la moral universal ni a las buenas costumbres". ${ }^{50}$ Há ainda casos nos quais o Estado é confessional, como no Reino Unido com a religião oficial Anglicana, na Grécia com a Igreja Ortodoxa, na Dinamarca e Finlândia com o Luteranismo, na Irlanda com a Igreja Católica e na Bulgária com a Igreja Ortodoxa Oriental. ${ }^{51}$

Importante salientar a existência ainda de modelos como no caso do Irã e de alguns países do Oriente Médio onde a religião islâmica prepondera e não ocorre uma separação entre a Igreja e o Estado. Na Coréia do Norte, por exemplo, já seria uma espécie de “Estado ateu", que se opõe a qualquer prática religiosa. ${ }^{52} \mathrm{~A}$ respeito, Ari Pedro Oro ${ }^{53}$ afirma e ilustra que esta laicidade "se mede pela existência ou não de uma dimensão religiosa da nação, pela existência ou não de uma religião de Estado, pelo lugar do ensino religioso na escola etc." É preciso observar que, mesmo nos casos onde o Estado não seja formalmente laico, podem ser estabelecidas políticas públicas desvinculadas da doutrina eclesial e assim sustentar uma adesão e legitimidade popular. ${ }^{54}$

Há que se referir que esta suposta neutralidade do Estado em relação à religião, fundamentada na separação entre o poder temporal e o espiritual, ao que parece, tem mais a ver com um ideal, um princípio retórico, do que com a realidade cotidiana. Como observa Ricardo Mariano:

Apesar da secularização do Estado, não há como deixar de notar que inexistem exemplos históricos concretos de países, por mais politicamente liberais que sejam em que tenha sucedido plena neutralização da ação estatal na economia religiosa. ${ }^{55}$

48 CONSTITUCION DE LA NACION ARGENTINA $(22$ de agosto de 1994) In: http://www.constitution.org/cons/argentin.htm. Acesso em 13 de Jun. 2019.

49 CONSTITUCIÓN POLITICA DEL ESTADO de 24 noviembre $2007 . \quad$ In: http://www.transparencialegislativa.org/wpcontent/uploads/2013/04/Constitucio\%CC\%81nBolivia.pdf. Acesso em 11 de Jun. 2019.

50 CONSTITUCION POLITICA DE LA REPUBLICA DE COSTA RICA (1949).In: http:// www.constitution.org/cons/costaric.htm. Acesso em 10 de Jun. 2019.

51 ORO, Ari Pedro. A laicidade no Brasil e no Oriente - algumas considerações. Civitas, Porto Alegre, v. 11, n. 2, maio-ago. 2011, p. 221-237.

52 LAFER, Celso. Estado Laico. In: Direitos Humanos, Democracia e República - Homenagem a Fábio Konder Comparato. São Paulo: Quartier Latin do Brasil, 2009, p. 227.

53 ORO, 2011, p. 222.

54 BLANCARTE, Roberto. Porque un Estado laico. In.: I Foro Centro americano de Libertades Laicas. 1a. ed. - San José, C.R.: Asociación Colectiva por el Derecho a Decidir, 2008, p. 19-32.

55 MARIANO, Ricardo. Análise sociológica do crescimento pentecostal no Brasil. Tese (Doutorado em Sociologia) - Universidade de São Paulo, São Paulo, 2001, p.118. 
No contexto brasileiro, uma significativa parcela (talvez a maioria) da população confunde os modelos acima apresentados quando se discute a respeito da laicidade. Nos últimos anos, especialmente com a presença incisiva de grupos conservadores representados pela "Frente Parlamentar Evangélica" no Congresso Nacional, inúmeras discussões acerca da implantação de políticas públicas de proteção às mulheres, negros, índios, minorias LGBT e grupos vulneráveis, os mais diversos, vem se acentuado um embate no sentido de que tais ações representariam a diluição de determinados valores e princípios em detrimento de um modelo de inclusão e cidadania alheio à verdade bíblica e cristã.

O crescente pluralismo religioso no Brasil tem suscitado estratégias e caminhos no sentido de transformar e consolidar as relações dos grupos religiosos com a esfera pública. Impulsionadas por seu crescente poderio religioso e demográfico, grandes igrejas pentecostais e neopentecostais, por exemplo, passaram a utilizar os meios de comunicação de massa para instrumentalizar a política nas últimas décadas. Concorrentes religiosos e adversários das demandas de um Estado laico não se acomodaram na hora de defender e promover seus interesses institucionais, seus valores, sua conduta e sua moral nos parlamentos e nos meios de comunicação. Com seu ativismo religioso, político e midiático, adquiriram maior poder e passaram a deter maior influência sobre questões de seu interesse. ${ }^{56}$

Atualmente muitas das perseguições às religiões de matriz africana, indígena e ao espiritismo, acontecem por meio de uma oposição movida por princípios ortodoxos e fundamentalistas que objetivam acabar com determinadas práticas de fé, converter os indivíduos e instaurar uma nova ordem social e religiosa.

Pastores, obreiros e fiéis partiram para a ofensiva. Saíram das trincheiras e puseram a artilharia das tropas do Senhor dos Exércitos para atacar os supostos representantes terrenos do diabo. Como resultado disso, relatos de imprensa mencionam a ocorrência [...] de invasões de centros e terreiros, imposições forçadas da Bíblia, agressões físicas a adeptos de cultos afro-brasileiros e espíritas e até de práticas de cárcere privado. ${ }^{57}$

É importante destacar que a expansão evangélica e neopentecostal das últimas décadas é um elemento importante para compreender os novos contornos das sensibilidades religiosas contemporâneas sob a perspectiva da liberdade religiosa. ${ }^{58} \mathrm{~A}$ multiplicação de espaços para atividades religiosas, o espetáculo das massas e a contínua penetração de agentes religiosos em todos os níveis do estado, acabou criando novas demandas e dilemas no tocante a força persuasiva da imagem do Brasil como nação católica,

56 FISCHMANN, Roseli. Estado Laico. São Paulo: Memorial da América Latina, 2008.

57 MARIANO, Ricardo. Pentecostais em ação: a demonização dos Cultos Afro-Brasileiros. In: SILVA, Vagner Gonçalves da (ORG.). Intolerância religiosa - impactos do neopentecostalismo no campo religioso afrobrasileiro. São Paulo: EDUSP, 2007. p. 137.

58 CATROGA, Fernando. Entre deuses e césares: secularização, laicidade e religião civil. Coimbra: Almedina, 2006. 
além de conferir novos instrumentos de poder e de influência na formação da opinião pública, modificando a percepção sobre o que corresponde ao interesse coletivo.

A "rivalidade" existente entre setores conservadores e movimentos que defendem a laicidade do Estado é antiga, mas com a promulgação da Constituição de 1988 houve uma nítida abertura para ações com o objetivo de assegurar o reconhecimento de grupos minoritários, salvaguardar os direitos humanos, os direitos sexuais, sociais e reprodutivos. Nesta luta estão engajados: jovens, estudantes, cientistas, juristas, artistas, feministas, homossexuais, educadores, políticos, autoridades e gestores públicos. ${ }^{59}$

Embora a defesa da laicidade seja um importante instrumento jurídico e político empregado pelos segmentos evangélicos na defesa de sua liberdade e de seus interesses institucionais, sua prioridade política tem consistido em estender sua ocupação religiosa no espaço público e ampliar seus próprios privilégios. ${ }^{60}$ Tanto que este ativismo tem gerado efeitos bastante contraditórios. Busca-se a laicidade, ataca-se a hegemonia católica e se persegue a pauta por privilégios e cada vez mais espaço no âmbito estatal. Em meio a debates polêmicos, e confrontos entre posições que defendem a laicidade do Estado, e religiosos de cunho conservador, é importante reafirmar na íntegra o artigo 18 da Declaração Universal dos Direitos Humanos, que propõe:

Toda a pessoa tem direito à liberdade de pensamento, de consciência e de religião; este direito implica a liberdade de mudar de religião ou de convicção, assim como a liberdade de manifestar a religião ou convicção, sozinho ou em comum, tanto em público como em privado, pelo ensino, pela prática, pelo culto e pelos ritos. ${ }^{61}$

As controvérsias suscitadas chamam a atenção para o papel do Estado e para o ativismo político de grupos religiosos na configuração do campo religioso brasileiro, no reconhecimento público das diferentes organizações religiosas, na regulação da ocupação religiosa de espaços públicos e na aquisição de concessão de benefícios a grupos religiosos. Também, lança luz à existência de múltiplos sentidos da laicidade em um país que permite aos seus muitos agentes a luta por demarcar, subjugar e manipular a laicidade do estado, através de muitas fronteiras.

É preciso reconhecer que um mercado religioso, como no caso brasileiro, tem impactado no recrudescimento das disputas religiosas que opõe denominações com desdobramentos na esfera pública, especialmente na arena política e na mídia eletrônica. Portanto, a laicidade constitucional brasileira apesar de balizar a atuação política de grupos religiosos laicos em determinados momentos, ao que parece, não dispõe ainda grandes

59 MARIANO, Ricardo. Laicidade à brasileira - católicos pentecostais e laicos em disputa na esfera pública. Civitas, Porto Alegre, v. 11, n. 2, maio-ago. 2011, p. 238-258.

60 MARTEL, Letícia de Campos Velho. "Laico, mas nem tanto": cinco tópicos sobre liberdade religiosa e laicidade estatal na jurisdição constitucional brasileira. Revista Jurídica. v. 9, n. 86, Ago./Set. Brasília, 2007, p.11-57.

61 CESE (Coordenadoria Ecumênica de Serviço). Declaração Universal dos Direitos Humanos. Recife: Fast Design, 2008, p. 6. 
artifícios jurídicos ou políticos para auxiliar nos processos de consolidação de secularização e a consequente laicidade estatal.

\section{Considerações finais}

Convém salientar que o tema é rico, amplo e complexo. A discussão envolve questões sérias no tocante a suas definições. É preciso acompanhar os debates em torno da temática e avaliar o que está por detrás de cada posição e argumento. Como critério amplo, pautados na Declaração Universal dos Direitos Humanos, cabe, sobretudo, estabelecer a liberdade de pensamento, consciência e religião para a preservação do Estado laico, da existência e coexistência de pessoas com diferentes crenças e adeptas de muitas tradições religiosas. Portanto, é tarefa comum, o engajamento para a criação de referenciais que permitam a convivência democrática e livre - convidando ao mesmo tempo para um olhar de justiça social.

São inegáveis as demandas estratégicas do papel da religião na vida política. No cenário internacional, são notórios e dramáticos os fatos que complicam a geopolítica mundial, ocasionados por interpretações de caráter fundamentalista. No Brasil, a presença da atividade política baseada e dirigida por princípios de fé poucas vezes suscitou tamanha controvérsia, com acirramentos e embates acalorados. Nesse contexto, é oportuno retomar a questão da laicidade, seu papel na vida da democracia e dos direitos humanos, seus nexos com a secularização e a tolerância.

Um Estado laico diferencia-se do teocrático, em que o poder religioso e o poder político se fundem, e também do confessional, em que há vínculos entre o poder político e uma religião. No Brasil Império, a religião oficial era a católica, ainda que outras confissões fossem permitidas e a liberdade de opinião, assegurada. Com a República, deu-se a separação da Igreja do Estado, ensejando a igualdade da liberdade dos cultos, a secularização dos cemitérios, o casamento civil e o registro civil para o nascimento e o falecimento de pessoas.

O princípio da laicidade não implica na perspectiva de uma sociedade civil laica. Com efeito, esta passou a se constituir como uma esfera autônoma e própria para o exercício da liberdade religiosa e de consciência, na qual o Estado não deveria interferir, pois a laicidade é a expressão do princípio da autonomia. É uma das formas de responder ao problema da intolerância. $\mathrm{O}$ apelo para que a democracia e os direitos humanos sejam resguardados.

Em um Estado laico, as normas religiosas das diversas confissões devem ser dirigidas apenas aos fiéis, e não colocados para todo o conjunto da sociedade. O ideal proposto pela consolidação da liberdade religiosa propõe a garantia das liberdades individuais. Desta maneira, a prerrogativa pública da laicidade é assegurar para todos os cidadãos e cidadãs uma perspectiva comum na qual possam exercitar a sua plena cidadania. É essa finalidade que cabe resguardar de modo que a religião não normatize as questões do 
espaço público, algo que, entrementes, tem se tornado um desafio da agenda política contemporânea.

\section{Referências}

ADRAGÃO, Paulo. A Liberdade Religiosa e o Estado. Coimbra: Almedina, 2002.

ANGELIN, Rosângela. O Reconhecimento da Identidade Multicultural diante da Dignidade da Pessoa Humana. In: MADERS, Angelita; ANGELIN, Rosângela (Org.). Multiculturalismo em Foco. Santo Ângelo: FuRI, 2010. p. 21-34.

ARENDT, Hannah. Origens do totalitarismo. São Paulo: Companhia das Letras, 1998.

ÁVILA, Humberto. Teoria dos Princípios: da definição à aplicação dos princípios jurídicos. São Paulo: Malheiros, 2004.

BARBOSA, Rui. Obras Completas, Vol. 4. Tomo 1, O Papa e o Concílio. Rio de Janeiro: Fundação Casa de Rui Barbosa, 1877.

BLANCARTE, Roberto. Porque un Estado laico. In.: I Foro Centro americano de Libertades Laicas. 1a. ed. - San José, C.R.: Asociación Colectiva por el Derecho a Decidir, 2008, p. 10-33. BOFF, Leonardo. In: http://jornalobservatorio.com.br/2015/04/28/leonardo-boff-participa-doprograma-espaco-publico/. Acesso em 03 de Jun. 2019.

CANOTILHO, José Joaquim Gomes. Direito Constitucional. Coimbra: Livraria Almedina, 1993.

CATROGA, Fernando. Entre deuses e césares: secularização, laicidade e religião civil. Coimbra: Almedina, 2006.

CESE (Coordenadoria Ecumênica de Serviço). Declaração Universal dos Direitos Humanos. Recife: Fast Design, 2008.

CONSTITUCION DE LA NACION ARGENTINA (22 de agosto de 1994) In: http://www.constitution.org/cons/argentin.htm. Acesso em 13 de Jun. 2019.

CONSTITUCIÓN POLITICA DEL ESTADO de 24 noviembre 2007. In: http://www.transparencialegislativa.org/wpcontent/uploads/2013/04/Constitucio\% CC\% 81nBolivia.pdf. Acesso em 11 de Jun. 2019.

CONSTITUCION POLITICA DE LA REPUBLICA DE COSTA RICA (1949). In: http://www.constitution.org/cons/costaric.htm. Acesso em 10 de Jun. 2019.

DAMATTA, Roberto. O que faz o Brasil, Brasil? Rio de Janeiro: Rocco, 1986.

DREHER, Martin N. Para Entender o Fundamentalismo. São Leopoldo: Editora UNISINOS, 2002.

FISCHMANN, Roseli. Estado Laico. São Paulo: Memorial da América Latina, 2008.

FREYRE, Gilberto. Interpretação do Brasil. São Paulo: Cia das Letras, 2001. 
GIUMBELLI, Emerson. Religião, estado e modernidade: notas a propósito de fatos provisórios. Revista de Estudos Avançados. São Paulo, v.18, n. 52, 2004, p.1-13

HALL, Stuart. Da diáspora - identidades e mediações. Belo Horizonte: UFMG, 2002.

HERVIEU-LÉGER, Daniele. O peregrino e o convertido - a religião em movimento. Petrópolis: Vozes, 2008.

INCONTRI, Dora; BIGHETO, Alessandro César. Ensino Religioso sem Proselitismo. É Possível? São Paulo: Mandruvá, 2005.

INSTITUTO BRASILEIRO DE GEOGRAFIA E ESTATÍSTICA - IBGE. Censo demográfico 2010. Características gerais da população, religião e pessoas com deficiência. Rio de Janeiro: 2010.

INTOLERÂNCIA RELIGIOSA. In:

http://www12.senado.gov.br/jornal/edicoes/2013/04/16/intolerancia-religiosa-e-crime-de-odio-efere-a-dignidade. Acesso em 01 de jun. 2019.

LAFER, Celso. Estado Laico. In: Direitos Humanos, Democracia e República - Homenagem a Fábio Konder Comparato. São Paulo: Quartier Latin do Brasil, 2009.

LEITE, Fábio Carvalho. Estado e Religião. A Liberdade Religiosa no Brasil. Curitiba: Juruá, 2014.

LOCKE, John. Carta a Respeito da Tolerância. São Paulo: Ibrasa, 1964.

LOREA, Roberto (Org.). Em defesa das liberdades laicas. Porto Alegre: Livraria do Advogado, 2008.

LUCKMANN, Thomas. A Religião Invisível. São Paulo: Olho d'água/Loyola, 2014.

MACHADO, Jónatas E. M. Estado Constitucional e Neutralidade Religiosa. Porto Alegre, Livraria do Advogado, 2013.

MAFRA, Maria Clara. Na Posse da Palavra: religião, conversão e liberdade pessoal em dois contextos nacionais. Lisboa: Imprensa de Ciências Sociais, 2002.

MAINWARING, Scott. Igreja católica e política no Brasil (1916-1985). São Paulo: Brasiliense, 1989.

MARIANO, Ricardo. Análise sociológica do crescimento pentecostal no Brasil. Tese (Doutorado em Sociologia) - Universidade de São Paulo, São Paulo, 2001.

. Pentecostais em ação: a demonização dos Cultos Afro-Brasileiros. In: SILVA, Vagner Gonçalves da (ORG.). Intolerância religiosa - impactos do neopentecostalismo no campo religioso afro-brasileiro. São Paulo: EDUSP, 2007. p. 119-148.

. Laicidade à brasileira - católicos pentecostais e laicos em disputa na esfera pública. Civitas, Porto Alegre, v. 11, n. 2, maio-ago. 2011, p. 238-258. 
MARTEL, Letícia de Campos Velho. "Laico, mas nem tanto": cinco tópicos sobre liberdade religiosa e laicidade estatal na jurisdição constitucional brasileira. Revista Jurídica. v. 9, n. 86, Ago./Set. Brasília, 2007, p.11-57.

MARTELLI, Stefano. A religião na sociedade pós-moderna: entre secularização e dessecularização. São Paulo: Paulinas, 1995.

MARTINS FILHO, Ives Gandra da Silva; NOBRE, Milton Augusto de Brito (Coord.). O Estado laico e a liberdade religiosa. São Paulo: LTr, 2011.

MONTERO, P. \& ALMEIDA, R. “O campo religioso brasileiro no limiar do século: problemas e perspectivas" In: RATTNER, H. (Org.). Brasil no limiar do século XXI. São Paulo: Edusp, 2000.

MONTERO, Paula. Secularização e espaço público: a reinvenção do pluralismo religioso no Brasil. Etnográfica: São Paulo. 13 (1) Maio de 2009, p. 7-16.

ORO, Ari Pedro. A laicidade no Brasil e no Oriente - algumas considerações. Civitas, Porto Alegre, v. 11, n. 2, Mai/Ago. 2011, p. 221-237.

ORO, Ari Pedro; URETA, Marcela. Religião e política na América Latina: uma análise da legislação dos países. Revista Horizontes Antropológicos, Porto Alegre, ano 13, n. 27, Jan./Jun. 2007, p. 281-310.

ORTIZ, Renato. Anotações sobre religião e globalização. Revista Brasileira de Ciências Sociais, v. 16, n. 47 , Out. 2001, p. 59-74.

Programa Nacional de Direitos Humanos (PNDH-3) / Secretaria Especial dos Direitos Humanos da Presidência da República - Brasília: SEDH/PR, 2010.

RIBEIRO, Boanerges. Igreja evangélica e República Brasileira: 1889-1930. São Paulo: O semeador, 1991.

RIVERA, Dario Paulo Barrera. Fragmentação do sagrado e crise das tradições na pósmodernidade. In: TRASFERETTI, José (Org.). Teologia na Pós-modernidade. São Paulo, Paulinas, 2003. p. 437-464.

RODRIGUES, Eder Bomfim. Estado Laico e Símbolos Religiosos no Brasil: As Relações entre Estado e Religião no Constitucionalismo Contemporâneo. Curitiba, Juruá, 2014.

SAFERNET. In: http://www.safernet.org.br/site/noticias/intoler\%C3\%A2ncia-religiosa\% C3\% A9-crime-\% C3\% B3dio-fere-dignidade. Acesso em 02 de Jun.2019.

SAMPAIO, José Adércio Leite. Direitos Fundamentais: retórica e historicidade. Belo Horizonte: Del Rey, 2004.

SARMENTO, Daniel. Livres e iguais: Estudos de direito constitucional. Rio de Janeiro: Lumen Juris, 2006.

. O Crucifixo nos Tribunais e a Laicidade do Estado. In: Roberto Lorea.

(Org.). Em defesa das Liberdades Laicas. Porto Alegre: Livraria do Advogado, 2008. p. 189-201.

Protestantismo em Revista | São Leopoldo | v. 45, n. 01 | p. 07-26| jan./jun. 2019

Disponível em: <http:// periodicos.est.edu.br/index.php/nepp> 
SCHRITZMEYER, Ana Lúcia Pastore. Sortilégio de Saberes: curandeiros e juízes nos tribunais brasileiros (1900-1990). São Paulo: IBCCRIM, 2004.

URI - Iniciativa das Religiões Unidas de Curitiba. Diversidade religiosa e direitos humanos. Curitiba: Gráfica da Assembleia Legislativa do Estado do Paraná, 2007.

WEINGARTNER, Jaime Neto. Liberdade Religiosa na Constituição: fundamentalismo, pluralismo, crenças, cultos. Porto Alegre: Livraria do Advogado, 2007. 